\title{
КОПІРАЙТИНГ СОЦІАЛЬНОЇ РЕКЛАМИ ЯК ІНСТРУМЕНТ СОЦІАЛЬНОГО МАРКЕТИНГУ: ЦІЛІ ТА ПІДХОДИ
}

\section{COPYRIGHTING OF SOCIAL ADVERTISING AS A TOOL OF SOCIAL MARKETING: GOALS AND APPROACHES}

\author{
Ткачук Світлана Валеріївна \\ кандидат економічних наук, доцент, \\ Національний університет харчових технологій \\ ORCID: https://orcid.org/0000-0002-8789-3555 \\ Стахурська Світлана Антонівна \\ кандидат економічних наук, доцент, \\ Національний університет харчових технологій \\ ORCID: https://orcid.org/0000-0001-6996-8907 \\ Стахурський Валерій Олександрович \\ старший викладач, \\ Національний університет харчових технологій \\ ORCID: https://orcid.org/0000-0001-9703-0238
}

\author{
Tkachuk Svitlana, Stakhurska Svitlana, Stakhurskyi Valerii \\ National University of Food Technologies
}

\begin{abstract}
У статті розглядається копірайтинг соціальної реклами як інструмент некомерційної складової соціального маркетингу. Соціальний маркетинг розглядається як поєднання некомерційного маркетингу (формування правильних потреб, раціонального споживання, правильного світогляду в цілому) та комерційного маркетингу (формування привабливої пропозиції з урахуванням правильних потреб). Сформульовані підходи до копірайтингу соціальної реклами залежно від сегменту цільової аудиторії та від мети рекламного повідомлення. Цільову аудиторію соціальної реклами запропоновано розділити на шість сегментів: не інформовані (головна мета - інформування про проблему), байдужі та пасивні (мета - переконати у важливості проблеми), не байдужі, але не активні (мета - інорормувати про способи вирішення проблеми, зокрема прості й прийнятні, а також про джерела виникнення проблеми), активні (потрібне лише інорормування про новини у сфрері певної проблеми), противники (найважчий сегмент; мета - переконати у важливості вирішення проблеми, але апелюючи до цінностей противника). Для кожного сегменту запропоновано використовувати існуючі фрормули копірайтингу, адаптувавши їх під повідомлення не комерційної, а соціальної реклами.

Ключові слова: маркетинг, соціальний маркетинг, копірайтинг, копірайтинг соціальної реклами, соціальна реклама, аудиторія реклами.
\end{abstract}

В статье рассматривается копирайтинг социальной рекламы как инструмент некоммерческой составляющей социального маркетинга. Социальный маркетинг рассматривается как сочетание некоммерческого маркетинга (формирование правильных потребностей, оптимального потребления, правильного мировоззрения в целом) и коммерческого маркетинга (формирование привлекательного предложения с учетом правильных потребностей). Сорормулированы подходы к копирайтингу социальной рекламы в зависимости от сегмента целевой аудитории и цели рекламного сообщения. Целевую аудиторию социальной рекламы предложено разделить на шесть сегментов: не информированные (главная цель - информирование о проблеме), безразличные и пассивные (цель - убедить в важности проблемы), не безразличные, но не активные (цель инорормировать о способах решения проблемы, в частности простых и приемлемых, а также об источниках возникновения проблемы), активные (нужно только информирование о новостях в сфрере определенной проблемы), противники (цель - убедить в важности решения проблемы, но апеллируя к ценностям противника). Для каждого сегмента предлагается использовать существующие фрормулы копирайтинга, адаптировав их под сообщения не коммерческой, а социальной рекламы.

Ключевые слова: маркетинг, социальный маркетинг, копирайтинг, копирайтинг социальной рекламы, социальная реклама, аудитория рекламы. 
The aim of the study is to formulate approaches to copywriting of social advertising depending on the segment of the target audience and the purpose of the advertising message. The relevance of the topic is related to the growing importance of social marketing and the importance of social advertising as a tool for non-profit component of social marketing. Methods of induction and deduction, systematization, generalization were used for research. The article considers copywriting of social advertising as a tool of non-commercial component of social marketing. Social marketing is seen as a combination of non-commercial marketing (the formation of the right needs, rational consumption, the right worldview in general) and commercial marketing (the formation of an attractive offer based on the right needs). Approaches to copywriting of social advertising depending on the segment of the target audience and the purpose of the advertising message are formulated. It is proposed to divide the target audience of social advertising into six segments: uninformed (the main goal is to inform about the problem), indifferent and passive (the goal of advertising message is to convince the importance of the problem), not indifferent, but not active (the goal is to inform about ways to solve problems, including simple and acceptable, as well as the sources of the problem), active (only information is needed on news in the field of a particular problem), opponents (the most difficult segment; the goal is to convince of the importance of solving the problem, but appealing to the values of the opponent segment). For each segment it is proposed to use the existing formulas of copywriting, adapting them to the message of not commercial but social advertising. The novelty of the study is formulation of the approach to creating advertising messages for opponents of a socially important problem. In practice, this segment is often overlooked, but similar formulas for copywriting can be used to influence it, but with an appeal to other values, namely the values of this segment. The practical significance of the study lies in the possibility of further use of the proposed approaches to create social advertising and the formation of the right needs of consumers.

Keywords: marketing, social marketing, copywriting, copywriting of social advertising, social advertising, advertising audience.

Постановка проблеми. Сучасний соціальний маркетинг невід'ємно пов'язаний із комерційним маркетингом та фрормуванням правильних потреб. Важливу роль відіграє соціальна реклама, підходам до копірайтингу якої присвячено не багато досліджень у порівнянні із комерційним копірайтингом, а деякі сегменти аудиторії реклами залишаються поза увагою. Виникає необхідність фрормулювання підходів до копірайтингу соціальної реклами залежно від сегменту цільової аудиторії та, відповідно, від мети рекламного повідомлення.

Аналіз останніх досліджень і публікацій. Питанням соціальної реклами присвячено більше популярних публікацій [1], втім $€$ і наукові праці [3]. Д. Альтман дає огляд яскравих прикладів соціальної реклами в аспекті історії іiі розвитку [1], О.В. Лаврик аналізує соціальну рекламу у медіа просторі [3]. Багато наукових праць присвячено соціальному маркетингу або соціальній відповідальності бізнесу: соціальновідповідальному маркетингу [2; 5], екологічному аспекту соціально-етичного маркетингу [4], соціальній відповідальності бізнесу в аспекті економічної безпеки [6]. Багато матеріалу присвячено формулам копірайтингу [7], але вони розглядаються переважно у суто комерційному аспекті, не деталізуючи специсріку соціальної реклами. Невирішеними залишаються питання специфріки копірайтингу соціальної, а не комерційної, реклами, деталізація цілей такої реклами, адаптація фрормул копірайтингу до соціальної реклами та виділення сегментів цільової аудиторії соціальної реклами.
Постановка завдання. Метою дослідження $€$ форомулювання підходів до копірайтингу соціальної реклами, як важливого інструменту соціального маркетингу, залежно від сегменту цільової аудиторії та від мети рекламного повідомлення.

Виклад основного матеріалу дослідження. Сучасний соціальний маркетинг поєднує в собі комерційні та некомерційні цілі: визначення та задоволення потреб клієнтів у поєднанні із просуванням соціальних цінностей. Як результат мають фрормуватись правильні потреби та привабливі маркетингові пропозиції із врахуванням цих потреб (раціонального споживання, здорового способу життя, збереження довкілля, екологічності, етичності, круелті-сррі тощо). Для просування комерційної пропозиції використовується стандартні маркетингові комунікації. У фрормуванні правильних потреб важливу роль відіграє соціальна реклама [1]. Існує безліч прийомів та формул копірайтингу для комерційної реклами, втім відносно мало досліджень присвячені копірайтингу соціальної реклами. Очевидно, ключові фрормули успіху будуть досить схожі. Перш, ніж приступати до фрормування некомерційного рекламного тексту, необхідно визначитись із адресатами, тобто із цільовою аудиторією (ЦА). Пропонуємо розділити ЦА соціальної реклами на наступні сегменти:

1) не інфрормовані: люди, які не знають про конкретну проблему;

2) байдужі: знають про проблему, але байдужі до неї;

3) пасивні: знають про проблему, загалом усвідомлюють її важливість але вважа- 
ють, що вирішення проблеми - справа інших інстанцій;

4) не байдужі: люди, які не байдужі до даної проблеми, але не завжди знають, як можна долучитись до ії вирішення. Сюди належать і люди, які не усвідомлюють всі шляхи виникнення проблеми;

5) активні: визнають проблему та активно борються за її вирішення;

6) противники: люди, які з певних особистих причин принципово не визнають проблему, або вважають за правильне не піднімати питання про неї.

Для кожного сегменту потрібно сорормувати відповідний підхід до рекламного повідомлення, зокрема до рекламного тексту (рис. 1).

Схеми написання рекламного тексту для сегментів «не інсрормовані», «байдужі», «пасивні» та «не байдужі» співпадають. Відрізнятись буде мета рекламного повідомлення. Не інсрормованих, перш за все, важливо поінформувати про існування проблеми, втім такі прийоми як підсилення («MorePain» у фрормулі PMHS), розуміння та переконання («Comprehension» та «Conviction» у форомулі АCCA) не будуть зайвими, а лише підсилять вплив рекламного тексту. Байдужих та пасивних слід переконати, тому схеми ACCA та PMHS будуть переважними: ACCA (Attention - Comprehension Conviction - Action) вміщує в собі переконуючі складові, а підсилення болю у формулі PMHS (Pain - MorePain - Hope - Solution) слугуватиме фрормою переконання, адже в соціальній рекламі велике значення мають емоційні чинники. Для зазначених сегментів може використовуватись і фрормула SSS (Star - Story -

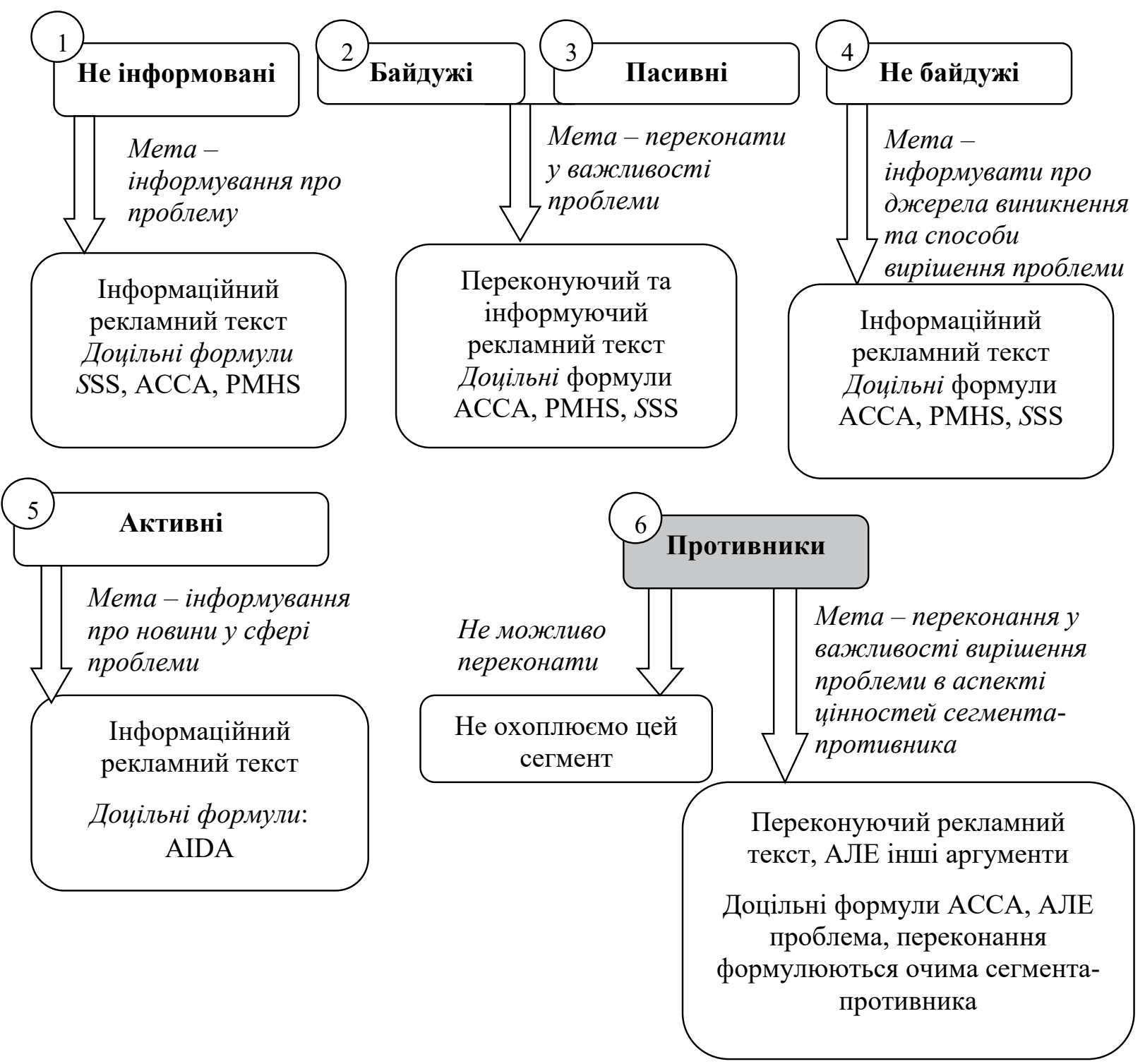

Рис. 1. Підходи до копірайтингу соціальної реклами залежно від сегменту Джерело: розроблено авторами на основі [1; 7] 
Solution). «Зіркою» виступатиме не комерційна пропозиція, а проблема («чорна зірка») або людина, істота чи явище, навколо яких розвивається сумна історія («нещаслива зірка»). «Зірка» та ії «Історія» у вдалій соціальній рекламі слугуватимуть не лише інфрормуванням, але й переконанням у важливості проблеми. Пасивних, крім переконання, важливо поінфрормувати про прості способи долучення до вирішення проблеми. Тут підійде аналогічний підхід, як і до не байдужих. Для сегменту «не байдужі» переконання не має першочергової мети, натомість їх важливо поінформувати про способи вирішення проблеми («solution», «hope», «action» у вищезазначених фрормулах), а також про джерела виникнення проблеми («star», «story», «comprehension»). Цей сегмент розуміє і усвідомлює важливість проблеми, але не знає, як допомогти її вирішенню. Наприклад, людина асоціює допомогу лише з грошовими внесками або участю у активістських акціях, але вона обмежена в грошах, а стиль життя не дозволяє їй стати активістом. Важливо повідомити про альтернативні способи участі у вирішення проблеми, прості (наприклад, сортування сміття, раціональне споживання - значний та простий внесок у збереження довкілля). Крім того, люди можуть не усвідомлювати, звідки приходить шкода. Приклад: людину турбує проблема нанесення шкоди тваринам, але вона не знає, що безпосередню шкоду наносять навіть кинуті склянки та пакети (заплутування, застрягання, ковтання) та жувальні гумки (ковтання, заклеювання дзьобу). Сегмент «активні» не потрібно інфрормувати про проблему або переконувати в іiі важливості, натомість слід надавати інфрормацію про нові способи вирішення проблеми та про благодійні чи соціальні акції, що очікуються. Каналами повідомлення будуть переважно соціальні мережі та мессенджери: спільноти людей, що відстоюють важливість проблеми. Додатково інфрормацію можна надати на зовнішній рекламі для залучення до акції не лише активних, але й не байдужих. Підійде класична фрормула AIDA [7]. Найважче працювати із сегментом «противники». Це ті, кого практично не можливо переконати, але можна спробувати зробити це, використавши інші мотиви. Частина людей, нажаль, буде поза ЦА рекламного повідомлення (якщо людина має патологічну хворобливу ненависть до дітей, людей з інвалідністю, тварин тощо - важко або неможливо переконати ії робити благо цим категоріям). Якщо ж людина не має патологічного ставлення, але $\epsilon$ противником боротьби 3 проблемою із певних суб'єктивних причин, можна переконати ії, апелюючи до важливих для неї понять. Візьмемо умовний приклад: проблема - тестування косметики на тваринах. Для не інформованих, пасивних та байдужих головний акцент у рекламному повідомленні слід робити на стражданнях тварин, висвітлювати сутність тестів, наголошувати на можливих кращих альтернативах. Для противників акценти у рекламі будуть іншими. Спочатку потрібно зрозуміти мотиви противників, їхні болі: чому вони чинять опір? У даному прикладі мотивами опору можуть бути страх за безпечність косметики у випадку заборони вівісекції, страх підняття цін на косметику завдяки забороні дешевих шкідливих домішок тощо. Апелювати потрібно до цих страхів. Ідея рекламного повідомлення (не відшліфований текст) матиме вигляд: «Тестують на тваринах, а споживає твоя дитина? Хіба цей тест дає гарантію безпеки? Обирай метод тестування косметики IN VITRO - точні результати для здоров'я твоїх близьких». При створенні рекламного повідомлення для противників копірайтер та рекламіст повинні враховувати можливі труднощі: розуміння істинних причин опору (у прикладі частина противників може дійсно турбуватись про себе і близьких, а частина просто прикриватись цим загальноприйнятним поняттям, турботою про близьких, приховуючи власні «скелети в шафі»); складання рекламного тексту, прийнятного для противника, не повинно суперечити ідеї соціальної реклами, знижувати важливість проблеми. Так, якщо у відшлісованому рекламному повідомленні з прикладу звести значення страждання тварин нанівець, повідомлення стане антирекламою соціальної проблеми вівісекції як такої).

При використанні усіх схем написання рекламного тексту також важливо розуміти, що значення кожної складової буде дещо відмінним від складових цих схем у комерційній рекламі. Вище було уточнене поняття «Зірки» із схеми «SSS». Складові «Увага», «Переконання», «Розуміння» із схеми АССА також матимуть інше «забарвлення»: більше емоційного впливу, більше значення візуальним складовим (зображенням). «Дія» не завжди буде пов'язана із активним закликом, а блок «Вирішення проблеми» у формулах «SSS» та «PMHS» інколи можуть не мати чіткого вираження, натомість рекламне повідомлення апелюватиме до існування певної проблеми взагалі.

Висновки 3 проведеного дослідження. Підсумовуючи вищевикладене, можна зробити наступні висновки:

1. Сучасний соціальний маркетинг повинен поєднувати дві складові: некомерційну (просу- 
вання соціально-важливих ідей, фрормування правильних потреб) та комерційну (формування та просування привабливої маркетингової пропозиції із врахуванням правильних потреб).

2. Важливим інструментом некомерційної складової соціального маркетингу є соціальна реклама.

3. Прийоми та схеми копірайтингу соціальної реклами частково схожі на ті, що застосовуються у комерційній рекламі, різниця полягає в тому, що просувається не комерційна пропозиція, а певна соціально важлива ідея чи проблема.

4. Цільову аудиторію соціальної реклами можна поділити на шість сегментів: не інфрор- мовані, байдужі, пасивні, не байдужі, активні, противники. Для кожного сегменту цілі та прийоми копірайтингу і візуалізації соціальної реклами будуть відрізнятись залежно від мети рекламного повідомлення та дієвих тригерів (чинників впливу).

5. Найважчий сегмент - це противники, які на практиці часто залишаються поза цільовою аудиторією соціальної реклами. Однак можливо віднайти підходи та інструменти впливу на частину цього сегменту, залучивши їх до вирішення проблеми, апелюючи до їхніх мотивів і больових точок, що будуть відмінними від мотивів та болів інших сегментів.

\section{СПИСОК ВИКОРИСТАНИХ ДЖЕРЕЛ:}

1. Альтман Д. Соціальна реклама: історія виникнення та яскраві кейси // Bazilik Media. 2020. URL: https://bazilik.media/sotsialna-reklama-istoriia-vynyknennia-ta-iaskravi-kejsy/

2. Герасимяк Н.В. Соціально-відповідальний маркетинг як одна з передових концепцій сучасного маркетингу. Економічні науки. Серія : Економіка та менеджмент. 2014. № 11. С. 71-79.

3. Лаврик О.В. Соціальна реклама в сучасному медіапросторі: до визначення поняття. 2008. URL: http://sn-philol.cfuv.ru/wp-content/uploads/2016/12/lavrik.pdf

4. Морохова В.О., Буняк Н.М. Екологічний аспект соціально-етичного маркетингу. Науковий вісник Нлту України. 2002. № 6. URL: https://cyberleninka.ru/article/n/ekologichniy-aspekt-sotsialno-etichnogo-marketingu

5. Новіков Д.Ф. Соціальна відповідальність маркетингу на ринку промислових підприємств. Бізнес-індрорм. 2018. № 11(490). URL: https://cyberleninka.ru/article/n/sotsialna-vidpovidalnist-marketingu-na-rinku-promislovih-pidpriemstv

6. Пахуча Е.В., Сєвідова І.О. Соціальна відповідальність бізнесу як складова економічної безпеки. Norwegian Journal of Development of the International Science. 2020. № 51-4. URL: https://cyberleninka.ru/ article/n/sotsialna-vidpovidalnist-biznesu-yak-skladova-ekonomichnoyi-bezpeki

7. 33 формулы отличного копирайтинга в PR и рекламе, для SMM и для SEO. Пишем быстро и вкусно! Школа системного интернет-маркетинга @ 2021. URL: https://cutt.ly/kUoEuyM

\section{REFERENCES:}

1. Altman, D. (2020) Sotsialna reklama: istoriia vynyknennia ta yaskravi keisy [Social advertising: history and bright cases]. Retrieved from: https://bazilik.media/sotsialna-reklama-istoriia-vynyknennia-ta-iaskravi-kejsy/ (in Ukrainian)

2. Herasymiak, N.V. (2014) Sotsialno-vidpovidalnyi marketynh yak odna z peredovykh kontseptsii suchasnoho marketynhu [Socially responsible marketing as one of the advanced concepts of modern marketing]. Ekonomichni nauky. Seriia: Ekonomika ta menedzhment, 11, 71-79. (in Ukrainian)

3. Lavryk, O.V. (2008) Sotsialna reklama v suchasnomu mediaprostori: do vyznachennia poniattia [Social advertising in the modern media space: to define the concept]. Retrieved from: http://sn-philol.cfuv.ru/wp-content/ uploads/2016/12/lavrik.pdf (in Ukrainian)

4. Morokhova, V.O., Buniak, N.M. (2002) Ekolohichnyi aspekt sotsialno-etychnoho marketynhu [Environmental aspect of socio-ethical marketing]. Naukovyi visnyk NLTU Ukrainy, 6. Retrieved from: https://cyberleninka.ru/ article/n/ekologichniy-aspekt-sotsialno-etichnogo-marketingu (in Ukrainian)

5. Novikov, D.F. (2018) Sotsialna vidpovidalnist marketynhu na rynku promyslovykh pidpryiemstv [Social responsibility of marketing in the market of industrial enterprises]. Biznes-inform, 11(490). Retrieved from: https://cyberleninka.ru/ article/n/sotsialna-vidpovidalnist-marketingu-na-rinku-promislovih-pidpriemstv (in Ukrainian)

6. Pakhucha, E.V., Sievidova, I.O. (2020) Sotsialna vidpovidalnist biznesu yak skladova ekonomichnoi bezpeky [Corporate social responsibility as a component of economic security]. Norwegian Journal of Development of the International Science, 51-4. Retrieved from: https://cyberleninka.ru/article/n/sotsialna-vidpovidalnist-biznesu-yak-skladova-ekonomichnoyi-bezpeki (in Ukrainian)

7. 33 formuly otlichnogo kopiraytinga $v$ PR i reklame. dlya SMM i dlya SEO. Pishem bystro i vkusno [33 formulas for excellent copywriting in PR and advertising, for SMM and for SEO. We write fast and tasty]. Retrieved from: https://cutt.ly/kUoEuyM 